\title{
Rodolphe Töppfer, Correspondance complète
}

\section{Lise Sabourin}

\section{(2) OpenEdition}

\section{Journals}

\section{Édition électronique}

URL : http://journals.openedition.org/studifrancesi/5375

DOI : 10.4000/studifrancesi.5375

ISSN : 2427-5856

\section{Éditeur}

Rosenberg \& Sellier

\section{Édition imprimée}

Date de publication : 1 décembre 2016

Pagination : $542-543$

ISSN : 0039-2944

\section{Référence électronique}

Lise Sabourin, «Rodolphe Töppfer, Correspondance complète », Studi Francesi [En ligne], 180 (LX | III) | 2016, mis en ligne le 01 janvier 2017, consulté le 18 septembre 2020. URL : http://

journals.openedition.org/studifrancesi/5375; DOI : https://doi.org/10.4000/studifrancesi.5375

\section{Ce document a été généré automatiquement le 18 septembre 2020}

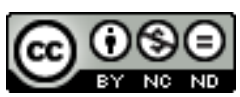

Studi Francesi è distribuita con Licenza Creative Commons Attribuzione - Non commerciale - Non opere derivate 4.0 Internazionale. 


\title{
Rodolphe Töppfer, Correspondance complète
}

\author{
Lise Sabourin
}




\section{RÉFÉRENCE}

RODOLPHE TÖPPFER, Correspondance complète, éditée et annotée par Jacques Droin, avec le concours de Danielle Buyssens et de Jean-Daniel Candaux, t. VII, 23 juin 1843-25 août 1844, Genève, Droz, 2015, 507 pp.

1 L'ample travail éditorial entamé par Jacques Droin pour la publication de la Correspondance complète de Töppfer continue, avec la parution du tome VII, qui va du 23 juin 1843 au 25 août 1844: c'est toujours la parution, cette fois du deuxième volume, des Voyages en zigzag qui occupe les missives entre l'écrivain et son cousin éditeur parisien, Jacques-Julien Dubochet, notamment autour des difficultés de transcription en gravures des dessins de l'auteur ou d'Alexandre Calame, selon les cas. S'y ajoutent l'édition illustrée des Nouvelles genevoises et la réédition du Presbytère.

2 Mais les ennuis de santé occupent beaucoup de place dans ce tome, vu les cures successives, la première pour sa vue à Lavey dans le canton de Vaud, la deuxième pour le foie à Vichy, que doit effectuer Rodolphe Töppfer, ce qui nous vaut bien des lettres à sa chère femme, Kity, et à ses quatre enfants, certes pleines d'affection, mais littérairement peu intéressantes, si ce n'est par les portraits pittoresques que fait le chef de famille esseulé de quelques-uns des curistes rencontrés. Le premier séjour donnera cependant naissance à des Souvenirs de Lavey, publiés au bénéfice des pauvres du village.

3 L'on ressent quelque désabusement, dû assurément à l'inefficacité de traitements assez éprouvants, mais aussi à l'évolution de la situation politique suisse, qui voit par exemple l'élection d'un antagoniste académique de Töppfer à la chaire de littérature ancienne et moderne de Genève, Albert Rilliet de Candolle, qu'Auguste De la Rive soutient contre l'avis de son ami, qui aurait préféré André Sayous son cousin. 